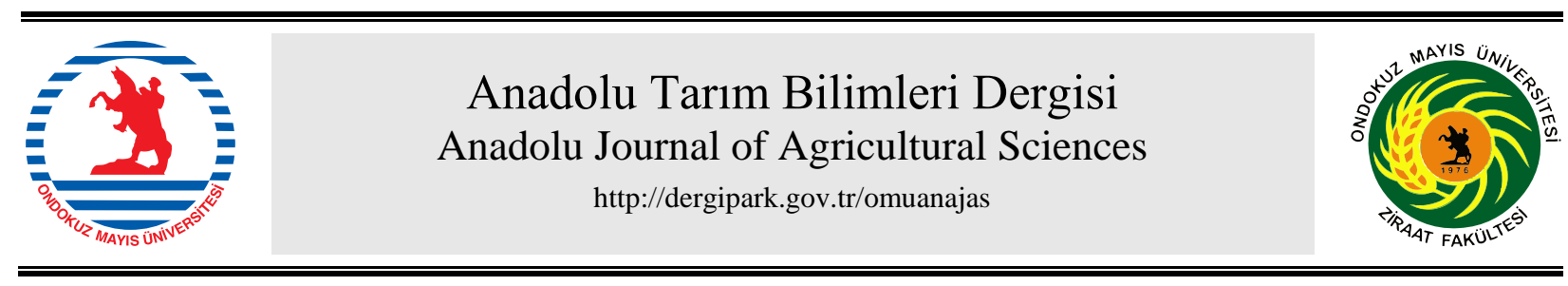

Araştırma/Research
Anadolu Tarım Bilim. Derg./Anadolu J Agr Sci, 34 (2019) ISSN: 1308-8750 (Print) 1308-8769 (Online) doi: $10.7161 /$ omuanajas.568403

\title{
Samsun ekolojik koşullarında beyaz atdişi hibrit mısır çeşit adaylarının performanslarının belirlenmesi
}

\author{
Murat Erdoğan ${ }^{\mathrm{a}}$ İsmail Sezer ${ }^{\mathrm{a} *}$, Hasan Akay $^{\mathrm{b}}$ \\ ${ }^{a}$ Ondokuz Mayıs Üniversitesi, Ziraat Fakültesi, Tarla Bitkileri Bölümü, Samsun \\ ${ }^{b}$ Ondokuz Mayls Üniversitesi, Bafra Meslek Yüksekokulu, Bitkisel ve Hayvansal Üretim Bölümü, Samsun \\ *Sorumlu yazar/corresponding author: isezer@omu.edu.tr \\ Geliş/Received 21/05/2019 Kabul/Accepted 14/06/2019
}

\begin{abstract}
ÖZET
Bu çalışma; Samsun-Bafra ve Çarşamba Ovası koşullarına uygun beyaz at dişi mısır çeşitlerinin verim, verim unsurları ve kalite kriterlerini belirlemek amacıyla, 2018 ana ürün mısır yetiştirme sezonunda, Karadeniz Tarımsal Araştırma Enstitüsünce geliştirilen 10 beyaz melez mısır çeşit adayı (TTBM2017-1, TTBM2017-2, TTBM2017-3, TTBM2017-4, TTBM2017-5, TTBM2017-6, Kompozit Beyaz, Tk353, Tk534 ve Tk384) ve 3 adet (Ada353, P31w86 ve P2948w) standart kullanılarak, tesadüf bloklar1 deneme deseninde 3 tekrarlamalı olarak yürütülmüştür. Araştırma sonucu, incelenen karakterlerde beyaz at dişi mısır genotipleri arasında farklılık istatistiki olarak önemli bulunmuştur. Genotiplerin tane verimleri 279.46- $1390.91 \mathrm{~kg} / \mathrm{da}$; çiçeklenme gün sayıs1 68.17-76.00 gün; bitki boyu 220.00, 306.67 cm; ilk koçan yüksekliği 75.00-103.33 cm; koçan görünümü (1-5) 1.67-2.67; koçan uzunluğu 10.52$20.53 \mathrm{~cm}$; koçan çap1 42.62-52.11 mm; koçanda tane sayıs $321.55-606.60$ adet; tane koçan oran1 \% 80.67- 83.93; bin tane ağırlığ1 218.00-350.41 g; hasatta tane nem \% 16.43-28.50; tanede ham protein oranı \% 10.62-12.85 ve tanede ham yağ oranı \% 3.80-5.45 olarak belirlenmiştir. Araştırma sonuçlarına göre, tane verimi bakımından, Samsun-Bafra ve Çarşamba lokasyonlarında Ada353 ve P31w86 çeşitlerinin daha üstün olduğu ve yetiştiricilikte önerilebileceği söylenebilir. Ayrıca, tanede ham yağ oranı bakımından TTBM2017-3 genotipi, tanede ham protein oran1 bakımdan ise Tk384 genotipi önerilebilir.
\end{abstract}

\section{Performance of white hybrid dent corn candidate cultivars in samsun conditions}

\section{ABSTRACT}

This study was conducted to determine yield, yield components and quality criteria of white dent corn cultivars suitable for Samsun-Bafra and Çarşamba Plain conditions. Experiments were conducted in maize main crop season of 2018 with 10 white hybrid maize candidate cultivars (TTBM2017-1, TTBM2017-2, TTBM2017-3, TTBM2017-4, TTBM2017-5, TTBM2017-6, Kompozit Beyaz, Tk353, Tk534 and Tk384) developed by Black Sea Agricultural Research Institute and 3 standard cultivars (Ada353, P31w86 and P2948w) in randomized blocks design with 3 replications. Variance analysis revealed significant differences in investigated traits of white dent corn genotypes. Genotype kernel yields varied between $279.46-1390.91 \mathrm{~kg} / \mathrm{da}$; number of days to flowering varied between $68.17-76.00$ day; the first cob heights varied between 75.00-103.33 cm; cob shape index (1-5) varied between 1.672.67; cob lengths between 10.52-20.53 cm; cob diameters between 42.62-52.11 mm; number of kernel per cob between 321.55-606.60; thousand-kernel weights between $218.00-350.41 \mathrm{~g}$; moisture at harvest between 16.43-28.50\%; kernel crude protein ratios between 10.62-12.85\% and finally kernel crude oil ratios varied between 3.80-5.45\%. It was concluded based on present findings that Ada353 and P31w86 cultivars were superior with regard to kernel yield in Samsun-Bafra and Çarşamba $1{ }^{\circ}$ Cations, thus they can be recommended for the region. It was also concluded that TTBM2017-3 genotype could be recommended for kernel crude oil ratio and Tk384 genotype could be recommended for kernel crude protein ratio.
Anahtar Sözcükler: Beyaz hibrit misir Verim Agronomik performans Çarşamba ovası Bafra ovas1

Keywords: White hybrid maize Yield Agronomic performance Çarşamba plain Bafra plain

(C) OMU ANAJAS 2019 


\section{Giriş}

Mısır bitkisi kullanım alanı çok geniş olan önemli bir kültür bitkisidir. Son yıllarda birçok endüstri alanında kullanılmasının yanı sıra, alternatif yakıt ve enerji arayışları kapsamında mısırın önemi daha da artmıştır. Mısır, dünyada buğday ve çeltikten sonra en fazla ekimi yapılan ve üretimi en fazla olan tahıl bitkisidir (Anonim, 2019). Dünya ortalamasının 580 $\mathrm{kg} / \mathrm{da}$ dolaylarında olduğu göz önüne alındığında, özellikle Adana, Sakarya ve Aydın illerinde (ana ürün koşullarında) optimum şartlarda birim alandan 1400$1600 \mathrm{~kg} / \mathrm{da}$ dolaylarında verim alınabilmesi gelecek için, hem alan hemde birim alan verimi artırma yönünden kendine yeter bir ülke konumuna gelme potansiyeli mevcuttur (Cengiz, 2016; Kün, 1997)

Mısır, Dünya'da ıslah çalışmalarının en yoğun şekilde sürdürüldüğü bitki olma özelliğini taşımaktadır. Ülkemizde 1950'lerde başlayan misır islah çalışmaları önemli sonuçları ortaya koymuştur. Ülkemizde tane ve silaj amaçlı ekimi ile öne çıkan mısır bitkisinde sürekli daha üstün çeşitlerin geliştirilmesi ve çiftçiye ulaştırılması amaçlanmıştır. Ancak, ülkemizde hibrit mısır tohumluğunun yaklaşı $\%$ 95'ini yabancı çeşitler oluşturmakta, yerli çeşitlerimizin payı \% 5 'i geçmemektedir. Bundan dolayı yabancı çeşitler için her yıl yurtdışına önemli oranda royalite bedeli ödenmektedir. Beyaz misır özellikle Karadeniz Bölgesinde tanesi gıda amaçlı tüketilmekte olup, Dünya'da en çok Güney Amerika'da üretilmekte ve tüketilmektedir. Ülkemizde iki yüzün üzerinde tescilli mısır çeşit ve hattı bulunmasına karşın beyaz mısır çeşidi birkaç tane ile sınırlıdır (Cengiz, 2006; Bayramoğlu ve Bozdemir, 2018; Dudley ve Moll 1969).

Dünyada Temmuz ayı ortalama sıcaklığı $20-27{ }^{\circ} \mathrm{C}$ olan bölgelerde en yoğun tane üretimi yapılmaktadır. Diğer taraftan mısır ıslahı ile ilgili sürdürülen araştırma ve geliştirme çalışmaları da aynı bölgelerde yer almaktadır. Samsun ili mısır kuşağı olarak tanımlanan bir bölgenin içerisindedir (Özata ve Kapar, 2011; Öner ve ark., 2011; Sezer ve Gülümser, 1999).

Ülkemizde 450 yıldan beri tarımı yapılan misırın ilk kültüre alındığı bölge olan Karadeniz bölgesinde halen insan yiyeceği olarak, doğrudan ve dolaylı olarak tüketimi söz konusudur. Ülkemize ilk gelen misır varyete grupları ve adaptasyonu olan çeşitler ise beyaz sert misırlardır (Kırtok, 1998). Ülkemizde geçmişten günümüze kadar ülke genelinde ve bölge araştırma enstitüsü tarafında geliştirilen çeşitler sarı sert yâda sarı at dişi mısır çeşitleridir. Ülkemizde hâlihazırda BATEM tarafindan geliştirilen sadece iki adet beyaz at dişi çeşit vardır. Karadeniz Tarımsal Araştırma Enstitüsü geçmişten günümüze kadar üzerinde çalıştı̆̆ beyaz sert ve at dişi hatlardan en uygun kombinasyon belirlenmeye çalışılmakta ve çeşit adaylarının verim ile kaliteleri ortaya konarak, insan yiyeceği olarak doğrudan ve dolaylı kullanılabilecek çeşit adaylarını belirlemeyi hedeflemektedir (Öner ve Gülümser, 2014). Bu çalışma ile beyaz hibrit mısır çeşitlerinin geliştirilmesi ile ihtiyaç duyulan un, ekmek, irmik, çorbalık ham madde, taze, közlemelik ve konserve tüketim olarak kullanımının artması sağlanacaktır (Kün, 1997).

Ülkemizde beyaz atdişi mısır çeşit sayısının azlığı ve tüketimimizi bile karşılayacak seviyede olmaması bu çalışmanın önemini ortaya koymaktadır.

Çalışmada, Karadeniz Bölgesinden toplanmış ve Karadeniz Tarımsal Araştırma Enstitü bünyesinde bulunan kendilenmiş beyaz atdişi mısır genotiplerden 10 adet beyaz melez mısır çeşit adayı ve 3 kontrol çeşit Samsun'un iki farklı lokasyonunda tane verimi, verim unsurları ve bazı kalite özeliklerinin belirlenmesi amaçlanmıştır.

\section{Materyal ve Yöntem}

\subsection{Materyal}

Çalışma, Samsun Karadeniz Tarımsal Araştırma Enstitüsünün, Bafra ve Çarşamba Deneme İstasyonlarında, 2018 ana ürün mısır yetiştirme sezonunda yürütülmüştür. Bafra deneme istasyonu; Samsun ilinin $52 \mathrm{~km}$ batısında, Bafra'nın yaklaşı $2 \mathrm{~km}$ kuzey doğusunda Bafra ovası içerisinde yer almaktadır. Merkezin toplam çalışma alanı 126 da olup, topografyası taban arazilerden oluşmaktadır. Çarşamba deneme istasyonu; Samsun ilinin $31 \mathrm{~km}$ doğusunda, Çarşamba ilçesinin batısında Çarşamba ovası içerisinde yer almaktadır. Merkezin toplam çalışma alanı 265 da olup, topografyası taban arazilerden oluşmaktadır.

Araştırmada bitki materyali olarak, Karadeniz Tarımsal Araştırma Enstitüsünce geliştirilen 10 beyaz melez mısır çeşit adayı ile 3 standart beyaz mısır çeşidi kullanılmıştır. Denemede kullanılan çeşit adayı mısırlar; TTBM2017-1, TTBM2017-2, TTBM2017-3, TTBM2017-4, TTBM2017-5, TTBM2017-6, Kompozit Beyaz, TK353, TK534 ve TK384'dür. Denemede, ADA353, P31w86 ve P2948w standart (kontrol) çeşitlerdir.

\subsection{Yöntem}

Bafra ilçesi, Orta Karadeniz Bölgesinde görülen 1lıman iklim özelliklerine sahip olup, deneme yerine ait ana ürün mısır yetiştirme sezonu (Nisan-Ekim ayları) iklim verileri dikkate alındığında, uzun yıllar ortalama sıcaklığ $18.2{ }^{\circ} \mathrm{C}, 2018$ yllında $19.7{ }^{\circ} \mathrm{C}$ olmuştur. $\mathrm{Bu}$ durum ana ürün mısır yetiştirme sezonu dikkate alındığında özellikle mayıs-eylül aylarının ortalama sıcaklık değerlerinde yaklaşık $1.5-2.0{ }^{\circ} \mathrm{C}$ artış söz konusudur. Nisbi nem ortalamas1 uzun yıllar ortalamasından (\% 0.8) daha yüksektir. Ana ürün mısır yetiştirme sezonu dikkate alındığında aylık toplam yağış miktarı toplamı $228.6 \mathrm{~mm}$ uzun yıllar ortalaması 360.6 mm olup, $132.0 \mathrm{~mm}$ daha az olmuştur.

Çarşamba ilçesi, Orta Karadeniz Bölgesinde görülen 1lıman iklim özellikleri sahip olup, deneme yerine ait yetiştirme sezonu ve uzun yıllar ortalaması olarak iklim verileri ana ürün mısır yetiştirme sezonu (Nisan-Ekim 
ayları) dikkate alındığında, uzun yıllar ortalaması 19.3 ${ }^{\circ} \mathrm{C}$ olurken 2018 yilında $20.6{ }^{\circ} \mathrm{C}$ olmuş olup, $1.3{ }^{\circ} \mathrm{C}$ fazlalık söz konusudur. $\mathrm{Bu}$ durum ana ürün misır yetiştirme sezonu dikkate alındığında özellikle mayıseylül aylarının ortalama sıcaklık değerlerinde yaklaşık $1.0-2.0{ }^{\circ} \mathrm{C}$ artış söz konusu olup, Eylül ayında $0.3{ }^{\circ} \mathrm{C}$ daha (hepsinde santigrad düzeltilmeli) düşük olmuştur. Nisbi nem ortalaması uzun yillar ortalamasından $(\%$ 1.2) daha az olmuştur. Ana ürün mısır yetiştirme sezonu dikkate alındığında aylık toplam yağış miktarı toplamı $534.5 \mathrm{~mm}$ uzun y1lar ortalamas $1493.5 \mathrm{~mm}$ olup, $41 \mathrm{~mm}$ daha fazla olmuştur.

Bafra lokasyonu, toprak tekstürü killi-tınlı, $\mathrm{pH}$ yönünden hafif alkali, organik madde oranı orta fosfor ve potasyum içeriği oldukça yüksektir. Kireç az ve tuz miktarı bakımından ise düşük niteliktedir. Çarşamba lokasyonu ise, toprak tekstürü killi-tınlı, $\mathrm{pH}$ yönünden hafif alkali, organik madde oranı az fosfor çok az ve potasyum içeriği oldukça yüksektir. Kireç orta ve tuz miktarı bakımından ise düşük niteliktedir.

Denemeler,"Tesadüf Blokları Deneme Deseni"ne göre 3 tekerrürlü olarak yürütülmüştür. Parsel boyutları sıra aras $70 \mathrm{~cm}$, sıra üzeri $18 \mathrm{~cm}$, parsel uzunluğu $5 \mathrm{~m}$ ve her parselde 4 sıra olacak şekilde elle ekim yapılmış olup, parsel alanı $14 \mathrm{~m}^{2}$ dir. Parseller arasinda $1 \mathrm{~m}$ mesafe bırakılmıştır.

Gübreleme ise, toprak tahlil sonuçlarına göre dekara $8 \mathrm{~kg}$ saf azot $(\mathrm{N}), 7-8 \mathrm{~kg}$ saf fosfor $\left(\mathrm{P}_{2} \mathrm{O}_{5}\right)$ ve 7-8 $\mathrm{kg}$ saf potasyum $\left(\mathrm{K}_{2} \mathrm{O}\right)$ gelecek şekilde taban gübresi verilmiştir. Ekim işlemi toprak sıcaklığının $10{ }^{\circ} \mathrm{C}$ nin üzerine çıktığ 1 dönemde ekim mibzer ile Çarşamba ve Bafra lokasyonlarına sirasıyla 27.04 .2018 ve 07.05 .2018 tarihlerinde yapılmıştır. Mısır fidelerinin uzunluğu 10$15 \mathrm{~cm}$ olunca birinci çapası ve seyreltme işlemi, mısır bitki uzunluğu $40-50 \mathrm{~cm}$ olunca da ikinci çapası ve boğaz doldurma işlemide yapılmıştır. Toprak analiz sonuçlarına göre boğaz doldurma ile birlikte denemelere üst gübre olarak \% 46'l1k üre gübresi uygulamak suretiyle parsellere $15.2 \mathrm{~kg} / \mathrm{da}$ saf azot verilmiştir. Beyaz at dişi mısır bitkisi büyüme mevsimi boyunca 460-610 mm suya ihtiyaç duymaktadır (Ziegler 2001). Gerekli olan sulamalar, tamburlu sulama sistemi ile verilmiștir. Sulama ișlemi tohumdaki siyah tabaka oluşana kadar devam edilmiştir. Yabancı otlarla mücadele, herbisitle yapılmış olup, sıra arasında gelişen yabancı otların yok edilmesi için iki kez de traktörle sıra arası çapası yapılmıştır.

Hasat, koçandaki tanelerin fizyolojik olum dönemini tamamlandıktan (siyah nokta oluştuğu dönem) sonra parsel kenarlarından birer sıra atılarak geri kalan sıralardaki koçanların hasadı el ile yapılmıştır.

Gözlem ve ölçümler için, parsel kenar tesir atıldıktan sonra 10'ar bitki ürerinden; bitki boyu $(\mathrm{cm})$, ilk koçan yüksekliği (cm), koçan görünümü (1-5), koçan uzunluğu $(\mathrm{cm})$, koçan çapı $(\mathrm{mm})$, koçanda tane sayısı (adet), bin tane ağırlığı (g), tane/koçan oranı (\%), hasat tane nemi $(\%)$, tane verimi $(\mathrm{kg} / \mathrm{da})$, tane ham protein
(\%), tane yağ oranı (\%) belirlenmiştir (Anonim, 2001; 2010).

\subsection{Verilerin değerlendirilmesi}

Veriler, Tesadüf Blokları Deneme Desenine göre lokasyonlar üzerinden birleştirilerek SPSS 17.0 paket programı ile varyans analizi (ANOVA) uygulanmış ve önemli olan özelliklerin farklılıklarını belirlemek için Duncan çoklu karşıllaştırma testi $\alpha=0.05$ önem düzeyinde belirlenmiştir. Harflendirmelerde küçük harf karekterlerinin yetmediği gruplamalarda büyük harf karekterleri ile devam edilmiştir.

\section{Bulgular ve Tartışma}

Beyaz atdişi hibrit mısır (Zea mays L.) çeşit adaylarının 2018 yılı Bafra ve Çarşamba lokasyonlarında elde edilen çiçeklenme gün sayısı, bitki boyu, ilk koçan yüksekliği, koçan görünümü, koçan uzunluğu, koçan çapı, koçan tane sayısı, tane/koçan oranı, bin tane ağırlığı, hasat tane nemi, tane ham protein oranı, tane ham yağ oranı ve tane verimi varyans analizi sonuçları Çizelge 1'de verilmiştir.

Çiçeklenme gün sayısı, bitki boyu, ilk koçan yüksekliği, koçan görünümü, koçan uzunluğu, koçan çapı, koçan tane sayısı, bin tane ağırlığı, hasat tane nemi, tane ham protein oranı, tane ham yağ oranı ve tane verimi bakımındangenotipler arasındaki fark istatistiki olarak çok önemli $(p<0.01)$ iken, koçanda tane sayısı ise önemli $(p<0.05)$ olarak tespit edilmiştir (Çizelge 1).

Lokasyonlar bakımından karakterler incelendiğinde; bitki boyu, hasat tane nemi, tane ham protein oranı ve tane ham yă oranı istatistiki olarak çok önemli $(\mathrm{p}<0.01)$ iken, bin tane ağırlığı özelliği yönünden ise önemli $(\mathrm{p}<0.05)$ olarak tespit edilmiştir (Çizelge 1$)$.

Genotip x lokasyon interaksiyonu bakımından ise bitki boyu, koçan uzunluğu, koçan çapı, koçan tane sayısı, bin tane ağırlığı, hasat tane nemi, tane ham protein oranı, tane ham yağ oranı ve tane verim değerleri incelendiğinde istatistiki olarak çok önemli $(\mathrm{p}<0.01)$, ilk koçan yüksekliği bakımından ise önemli $(\mathrm{p}<0.05)$ bulunurken, diğer parametreler arasında farklılık istatistiki olarak önemlilik bulunmamıştır (Çizelge 1).

Birleştirilmiş varyans analiz sonucunda P2948w genotipi 76.00 gün ile en uzun iken, TTBM2017-1 genotipi ise 68.17 gün ile en kısa çiçeklenme gün sayısına sahiptir. Yapılan DUNCAN çoklu karşılaştırma testi sonucuna göre, 76.00 gün ile P2948w genotipi ilk sırada yer almıştır (Çizelge 2). Öz ve ark. (2008) 71.0 75.0 gün; Tezel ve Aksoyak (2008) 72.0 - 75.7 gün; Özata ve ark. (2013) 61.5 - 68.00 gün; Öz ve Cengil (2016) 70.8 - 74.7 gün olduğu tespit edildikleri çalışmalar ile paralellik göstermektedir. 
Çizelge 1. Araştırma verileri sonuçlarına ait varyans analiz tablosu

\begin{tabular}{l|c|c|c|c|c|c|c|c}
\hline $\begin{array}{l}\text { Varvasyon } \\
\text { Kaynağı }\end{array}$ & S.D. & ÇGS & BB & IKY & KG & KU & KÇ & KTS \\
\hline Genel & 77 & 9.45 & 640.04 & 120.13 & 0.28 & 5.62 & 21.91 & 15499.77 \\
Genotipler & 12 & $27.56 * *$ & $1934.03 * *$ & $270.14 * *$ & $0.45 *$ & $17.52 * *$ & $48.45 * *$ & $37149.69 * *$ \\
Blok & 2 & 6.27 & 90.71 & 26.92 & 0.34 & 3.39 & 27.56 & $20350.41 *$ \\
Lokasyon & 1 & 5.65 & $4770.51 * *$ & 216.67 & 0.03 & 5.45 & 0.22 & 6813.35 \\
Gen. x Lok. İnt. & 12 & 9.38 & $1575.37 * *$ & $171.53 *$ & 0.41 & $8.90 * *$ & $43.73 * *$ & $34975.79 * *$ \\
Hata & 50 & 5.32 & 44.37 & 73.59 & 0.22 & 2.07 & 10.52 & 5609.25 \\
\hline CV \% & & $\mathbf{3 . 2 7}$ & $\mathbf{2 . 5 5}$ & $\mathbf{9 . 0 3}$ & $\mathbf{2 2 . 5 5}$ & $\mathbf{8 . 2 7}$ & $\mathbf{6 . 7 4}$ & $\mathbf{1 5 . 6 7}$ \\
\hline Genel & & $\mathbf{T K O}$ & $\mathbf{B T A}$ & $\mathbf{H T N}$ & $\mathbf{T H P O}$ & $\mathbf{T H Y O}$ & \multicolumn{2}{|c}{ TV } \\
Genotipler & 77 & 1.47 & 2624.07 & 10.31 & 1.49 & 1.26 & 85556.39 \\
Blok & 12 & 1.13 & $7731.64 * *$ & $19.71 * *$ & $3.10 * *$ & $1.45 *$ & $232189.10 * *$ \\
Lokasyon & 2 & $6.64 *$ & 270.07 & 0.68 & 0.17 & 1.41 & 71700.95 \\
Gen. x Lok. İnt. & 1 & 2.28 & $6720.32 *$ & $463.80 * *$ & $19.77 * *$ & $13.50 * *$ & 11651.50 \\
Hata & 12 & 1.49 & $3361.34 * *$ & $3.82 * *$ & $2.05 * *$ & $2.42 * *$ & $147270.50 * *$ \\
\hline CV \% & 50 & 1.33 & 1233.55 & 0.93 & 0.65 & 0.68 & 37585.48 \\
\hline
\end{tabular}

$(*) \mathrm{p}<0.05,\left({ }^{* *}\right) \mathrm{p}<0.01$ hata sınırları içerisinde istatistiki olarak önemli

S.D.: Serbestlik Derecesi; CV \%: Varyasyon Katsayısı; ÇGS: Çiçeklenme Gün Sayısı; BB: Bitki Boyu; İKY: İlk Koçan Yüksekliği; KG: Koçan Görünümü; KU: Koçan Uzunluğu; KÇ: Koçan Çapı; KTS: Koçan Tane Sayısı; TKO: Tane Koçan Oranı; BTA: Bin Tane Ağırlığı; HTN: Hasat Tane Nemi; THPO: Tane Ham Protein Oranı; THYO: Tane Ham Yağ Oranı; TV: Tane Verimi

Genotipler bakımından birleştirilmiş analiz sonucunda P31w86 çeşidi $286.67 \mathrm{~cm}$ ile en uzun, Tk384 genotipi ise 230.00 ile en kisa bitki boyu ölçülmüştür. DUNCAN çoklu karşılaştırma testi sonucunda Kompoze beyaz, P31w86 ve TTBM2017-6 genotipleri ilk grupta iken Tk534 ve Tk384 genotipleri son grupta yer almıştır. Beyaz mısır genotiplerinin bitki boyu, lokasyon ortalamaları olarak, Bafra ve Çarşamba ovası koşullarında sırasıyla 253.85 ve $269.49 \mathrm{~cm}$ olarak aralarında istatistiki çok önemli çıkmıştır. Lokasyon $\times$ genotip interaksiyonu incelendiğinde en yüksek bitki boyu Çarşamba lokasyonu TTBM2017-6 (306.67 cm) ve $\mathrm{P} 2948 \mathrm{w}(300.00 \mathrm{~cm})$ genotiplerinde iken en düşük ise $220.00 \mathrm{~cm}$ ile Çarşamba lokasyonu Tk384 genotiptedir (Çizelge 2). Gençtürk (2007) 205.3 - 245.3 cm; Palta ve ark. (2011) 262.8 cm; Öz ve ark. (2008) 245.0 - $292.0 \mathrm{~cm}$; Tezel ve Aksoyak (2008) 258.0 $338.0 \mathrm{~cm}$; Sayaslan ve ark. (2010) $226.5-283.4 \mathrm{~cm}$; Özata ve ark. (2013) 255.5 - $335.8 \mathrm{~cm}$; Kuşvuran ve Nazlı (2014) 265 cm; Öz ve Cengil (2016) 269.0 $298.0 \mathrm{~cm}$ olduğu tespit edildikleri çalışmalar ile paralellik göstermektedir.

Çizelge 2. Genotiplerin Bafra ve Çarşamba lokasyonu çiçeklenme gün sayısı ve bitki boyu ortalamaları

\begin{tabular}{|c|c|c|c|c|c|c|c|c|}
\hline \multirow{3}{*}{$\begin{array}{l}\text { Genotipler } \\
\text { TTBM2017-1 }\end{array}$} & \multicolumn{4}{|c|}{ Çiçeklenme gün sayısı (gün) } & \multicolumn{4}{|c|}{ Bitki boyu (cm) } \\
\hline & \multirow{2}{*}{$\begin{array}{l}\text { Bafra } \\
68.33\end{array}$} & \multirow{2}{*}{$\frac{\text { Çarşamba }}{68.00}$} & \multicolumn{2}{|c|}{ Ortalama } & \multirow{2}{*}{$\begin{array}{r}\text { Bafra } \\
228.33 \mathrm{mn}\end{array}$} & \multirow{2}{*}{$\begin{array}{c}\text { Çarşamba } \\
290.00 \text { bc }\end{array}$} & \multicolumn{2}{|c|}{ Ortalama } \\
\hline & & & 68.17 & $\mathrm{c}$ & & & 259.17 & e \\
\hline TTBM2017-2 & 69.00 & 68.00 & 68.50 & $\mathrm{c}$ & $250.00 \mathrm{hij}$ & $250.00 \mathrm{hij}$ & 250.00 & $\mathrm{f}$ \\
\hline TTBM2017-3 & 71.00 & 69.67 & 70.33 & $\mathrm{bc}$ & $238.33 \mathrm{klm}$ & $250.00 \mathrm{hij}$ & 244.17 & $\mathrm{f}$ \\
\hline TTBM2017-4 & 69.33 & 72.33 & 70.83 & bc & $276.67 \mathrm{def}$ & $270.00 \mathrm{fg}$ & 273.33 & $\mathrm{bc}$ \\
\hline ТТВМ2017-5 & 69.00 & 68.67 & 68.83 & $\mathrm{c}$ & $241.67 \mathrm{ijk}$ & $286.67 \mathrm{~cd}$ & 264.17 & de \\
\hline TTBM2017-6 & 69.00 & 69.67 & 69.33 & $\mathrm{c}$ & $251.67 \mathrm{~h} 1$ & $306.67 \mathrm{a}$ & 279.17 & $a b$ \\
\hline Komp. Beyaz & 73.67 & 71.33 & 72.50 & $\mathrm{~b}$ & $290.00 \mathrm{bc}$ & $281.67 \mathrm{cde}$ & 285.83 & $\mathrm{a}$ \\
\hline Ada353 & 68.33 & 69.33 & 68.83 & $\mathrm{c}$ & $260.00 \mathrm{gh}$ & $276.67 \mathrm{def}$ & 268.33 & $\mathrm{~cd}$ \\
\hline P31w86 & 66.67 & 73.33 & 70.00 & bc & $286.67 \mathrm{~cd}$ & $286.67 \mathrm{~cd}$ & 286.67 & $\mathrm{a}$ \\
\hline P2948w & 77.33 & 74.67 & 76.00 & $\mathrm{a}$ & $225.00 \mathrm{n}$ & $300.00 \mathrm{ab}$ & 262.50 & de \\
\hline Tk353 & 70.67 & 70.33 & 70.50 & $\mathrm{bc}$ & 271.67 ef & $255.00 \mathrm{~h}$ & 263.33 & $\mathrm{de}$ \\
\hline Tk534 & 71.67 & 73.33 & 72.50 & $\mathrm{~b}$ & $240.00 \mathrm{jkl}$ & $230.00 \mathrm{lmn}$ & 235.00 & $\mathrm{~g}$ \\
\hline Tk384 & 69.00 & 71.33 & 70.17 & $\mathrm{bc}$ & $240.00 \mathrm{jkl}$ & $220.00 \mathrm{n}$ & 230.00 & $\begin{array}{l}0 \\
\mathrm{~g}\end{array}$ \\
\hline Ortalama & 70.23 & 70.77 & 70.50 & & 253.85 & 269.49 & 261.67 & \\
\hline
\end{tabular}

*Aynı harfle gösterilen ortalamalar arasında fark yoktur.

Genotipler bakımından birleştirilmiş analiz sonucuna göre, ilk koçan yüksekliği P31w86 genotipi $104.17 \mathrm{~cm}$ ile en uzun iken, TTBM2017-5 genotipi $83.33 \mathrm{~cm}$ olarak en kısa ölçülmüştür. Yapılan DUNCAN çoklu karşılaştırma testi sonucuna göre P31w86 (104.17 cm), TTBM2017-1 (97.50 cm),
TTBM2017-4 $(97.50 \mathrm{~cm})$, TTBM2017-6 $(100.83 \mathrm{~cm})$, Kompozit beyaz $(98.33 \mathrm{~cm})$, Ada353 $(100.83 \mathrm{~cm})$, P2948w (96.67 cm), Tk353 (96.67 cm), Tk384 (98.32 $\mathrm{cm})$ genotipleri ilk sırada yer almıştır. Lokasyon genotip interaksiyonu bakımından incelendiğinde ise en yüksek ilk koçan yüksekliği $115.00 \mathrm{~cm}$ ile Bafra lokasyonu 
P31w86 genotipte iken en kisa ise $75.00 \mathrm{~cm}$ ile Bafra lokasyonu TTBM2017-5 genotipte tespit edilmiştir (Çizelge 3). Palta ve ark. (2011) $112.6 \mathrm{~cm}$; Öz ve ark. (2008) 81.0 - $100.0 \mathrm{~cm}$; Tezel ve Aksoyak (2008) 101.0 - $148.0 \mathrm{~cm}$; Sayaslan ve ark. (2010) $100.4-141.4 \mathrm{~cm}$; Özata ve ark. (2013) $109.2-145.0 \mathrm{~cm}$; Kuşvuran ve Nazlı (2014) $123.0 \mathrm{~cm}$; Öz ve Cengil (2016) 95.0 $117.0 \mathrm{~cm}$ olduğu tespit edildikleri çalışmalar ile paralellik göstermektedir.
Genotipler bakımından birleştirilmiş analiz sonucunda P2948w genotipi 2.67 ile en iyi değere sahip iken TTBM2017-4 genotipi 1.67 ile en kötü değere sahiptir. Yapılan DUNCAN çoklu karşılaştırma testi sonucuna göre 2.67, 2.42, 2.33, 2.27, 2.17 ile sirasiyla P2948w, Tk384, Tk353, Komp. Beyaz, Tk534genotipleri ilk sırada yer alımışır (Çizelge 3).

Çizelge 3. Genotiplerin Bafra ve Çarşamba lokasyonu ilk koçan yüksekliği ve koçan görünümü ortalamaları

\begin{tabular}{|c|c|c|c|c|c|c|c|}
\hline & \multicolumn{3}{|c|}{ İlk koçan yüksekliği (cm) } & \multicolumn{4}{|c|}{ Koçan görünümü } \\
\hline Genotipler & Bafra & Çarşamba & Ortalama & Bafra & Çarşamba & Ort & \\
\hline TTBM2017-1 & 93.33 b-f & $101.67 \mathrm{a}-\mathrm{d}$ & $97.50 \quad a b c$ & 2.00 & 2.00 & 2.00 & $\mathrm{bc}$ \\
\hline TTBM2017-2 & 86.67 efg & 93.33 b-f & 90.00 & 1.83 & 2.00 & 1.92 & $\mathrm{bc}$ \\
\hline ТТВМ2017-3 & $85.00 \mathrm{fg}$ & $88.33 \mathrm{~d}-\mathrm{g}$ & 86.67 & 1.67 & 2.33 & 2.00 & $\mathrm{bc}$ \\
\hline ТТВМ2017-4 & $101.67 \mathrm{a}-\mathrm{d}$ & 93.33 b-f & 97.50 & 1.33 & 2.00 & 1.67 & $\mathrm{c}$ \\
\hline TTBM2017-5 & $75.00 \mathrm{~g}$ & $91.67 \mathrm{c}-\mathrm{f}$ & 83.33 & 1.67 & 2.00 & 1.83 & $\mathrm{bc}$ \\
\hline ТТВМ2017-6 & $100.00 \mathrm{~b}-\mathrm{e}$ & $101.67 \mathrm{a}-\mathrm{d}$ & 100.83 & 1.83 & 2.00 & 1.92 & $\mathrm{bc}$ \\
\hline Komp. Beyaz & $100.00 \mathrm{~b}-\mathrm{e}$ & 96.67 b-f & 98.33 & 2.53 & 2.00 & 2.27 & $a b c$ \\
\hline Ada353 & $106.67 \mathrm{ab}$ & $95.00 \mathrm{~b}-\mathrm{f}$ & 100.83 & 1.83 & 2.00 & 1.92 & $\mathrm{bc}$ \\
\hline P31w86 & $115.00 \mathrm{a}$ & 93.33 b-f & 104.17 & 1.83 & 2.17 & 2.00 & $\mathrm{bc}$ \\
\hline P2948w & $105.00 \mathrm{abc}$ & 88.33 d-g & 96.67 & 3.33 & 2.00 & 2.67 & $\mathrm{a}$ \\
\hline Tk353 & $100.00 \mathrm{~b}-\mathrm{e}$ & 93.33 b-f & 96.67 & 2.33 & 2.33 & 2.33 & $a b$ \\
\hline Tk534 & $85.00 \mathrm{fg}$ & $83.33 \mathrm{fg}$ & 84.17 & 2.17 & 2.17 & 2.17 & $a b c$ \\
\hline Tk384 & $103.33 \mathrm{abc}$ & 93.33 b-f & 98.33 & 2.50 & 2.33 & 2.42 & $\mathrm{ab}$ \\
\hline Ortalama & 96.67 & 93.33 & 95.00 & 2.07 & 2.10 & 2.08 & \\
\hline
\end{tabular}

* Aynı harfle gösterilen ortalamalar arasında fark yoktur.

Çizelge 4. Genotiplerin Bafra ve Çarşamba lokasyonu koçan uzunluğu ve koçan çapı ortalamaları

\begin{tabular}{|c|c|c|c|c|c|c|c|c|}
\hline \multirow[b]{2}{*}{ Genotipler } & \multicolumn{4}{|c|}{ Koçan uzunluğu (cm) } & \multicolumn{4}{|c|}{ Koçan çapı (mm) } \\
\hline & Bafra & Çarşamba & Orta & & Bafra & Çarşamba & Orta & ma \\
\hline TTBM2017-1 & 18.65 a-f & $17.11 \mathrm{~d}-1$ & 17.88 & a-e & $51.19 \mathrm{a}-\mathrm{d}$ & 47.97 b-f & 49.58 & $a b$ \\
\hline ТTВМ2017-2 & 18.48 a-f & $18.21 \mathrm{a}-\mathrm{g}$ & 18.35 & $a-d$ & $52.56 \mathrm{ab}$ & $51.67 \mathrm{a}-\mathrm{d}$ & 52.11 & $\mathrm{a}$ \\
\hline ТТВМ2017-3 & $16.29 \mathrm{f}-1$ & $16.88 \mathrm{e}-1$ & 16.59 & de & 50.96 a-d & 49.53 a-e & 50.24 & $\mathrm{ab}$ \\
\hline TTBM2017-4 & $19.75 \mathrm{abc}$ & 16.02 gh1 & 17.89 & a-e & $46.59 \mathrm{~d}-\mathrm{g}$ & 49.31 a-e & 47.95 & $a b$ \\
\hline TTBM2017-5 & $17.25 \mathrm{~d}-1$ & $17.50 \mathrm{c}-\mathrm{h}$ & 17.38 & cde & $49.01 \mathrm{~b}-\mathrm{e}$ & $43.03 \mathrm{~b}-\mathrm{e}$ & 46.02 & $\mathrm{bc}$ \\
\hline ТТВМ2017-6 & $17.32 \mathrm{~d}-1$ & $16.42 \mathrm{f}-1$ & 16.87 & cde & $47.02 \mathrm{c}-\mathrm{g}$ & $50.51 \mathrm{f}-1$ & 48.77 & $a b$ \\
\hline Komp. Beyaz & 19.45 a-d & $18.06 \mathrm{~b}-\mathrm{g}$ & 18.76 & $a b c$ & $54.76 \mathrm{a}$ & 42.22 a-e & 48.49 & $a b$ \\
\hline Ada353 & $20.25 \mathrm{ab}$ & $18.56 \mathrm{a}-\mathrm{f}$ & 19.41 & $\mathrm{ab}$ & $52.25 \mathrm{abc}$ & 51.92 gh1 & 52.09 & $\mathrm{a}$ \\
\hline P31w86 & 18.97 a-e & $20.53 \mathrm{a}$ & 19.75 & $\mathrm{a}$ & $47.45 \mathrm{~b}-\mathrm{g}$ & $50.62 \mathrm{abc}$ & 49.04 & $a b$ \\
\hline P2948w & 16.02 ghı & $16.63 \mathrm{e}-1$ & 16.33 & $\mathrm{e}$ & $48.28 b-f$ & 46.57 a-d & 47.43 & $\mathrm{~b}$ \\
\hline Tk353 & $16.74 \mathrm{e}-1$ & $16.52 \mathrm{f}-1$ & 16.63 & de & $47.49 \mathrm{~b}-\mathrm{g}$ & $48.48 \mathrm{~d}-\mathrm{g}$ & 47.98 & $a b$ \\
\hline Tk534 & $10.52 \mathrm{j}$ & $15.43 \mathrm{~h} 1$ & 12.98 & $\mathrm{f}$ & 39.99 h1 & $45.26 \mathrm{~b}-\mathrm{e}$ & 42.62 & $\mathrm{c}$ \\
\hline Tk384 & $20.10 \mathrm{ab}$ & $15.05 \quad 1$ & 17.58 & b-e & $38.89 \quad 1$ & 47.97 b-f & 43.43 & $\mathrm{c}$ \\
\hline Ortalama & 17.68 & 17.15 & 17.41 & & 48.19 & 48.08 & 48.13 & \\
\hline
\end{tabular}

* Aynı harfle gösterilen ortalamalar arasında fark yoktur.

Genotipler bakımından birleştirilmiş analiz sonucunda P31w86 genotipi $19.75 \mathrm{~cm}$ ile en uzun iken, Tk534 genotipi $12.98 \mathrm{~cm}$ olarak en kısa ölçülmüştür. Yapılan DUNCAN çoklu karşılaştırma testi sonucuna göre 19.75, 19.41, 18.76, 18.35, $17.89 \mathrm{~cm}$ ile sirasiyla P31w86, Ada353, Komp. Beyaz, TTBM2017-2, TTBM2017-4, genotipleri ilk sırada yer almıştır. Lokasyon genotip interaksiyonu bakımından incelendiğinde ise en uzun koçan uzunluğu $20.53 \mathrm{~cm}$ ile Çarşamba lokasyonu P31w86 genotipte iken en düşük ise $10.52 \mathrm{~cm}$ ile Bafra lokasyonu Tk384 genotipte tespit edilmiştir (Çizelge 4). Ayrancı ve Sade (2004) 16.1 -
$21.5 \mathrm{~cm}$; Palta ve ark. (2011) $21.6 \mathrm{~cm}$; Sayaslan ve ark. (2010) 19.1 - 22.0 cm; Kuşvuran ve Nazlı (2014) 20.98 $\mathrm{cm}$; Öz ve Cengil (2016) 20.5 - $24.6 \mathrm{~cm}$ olduğu tespit edildikleri çalışmalar ile paralellik göstermektedir.

Genotipler bakımından birleştirilmiş analiz sonucunda TTBM2017-2 genotipleri sirasiyla 52.11 $\mathrm{mm}$ ile en yüksek iken, Tk534 genotipleri sırasıyla $42.62 \mathrm{~mm}$ ile en kısa ölçülmüştür. Yapılan DUNCAN çoklu karşılaştırma testi sonucuna göre 52.11, 52.09, $50.24,49.58,49.04,48.77,48.49,47.98,47.95 \mathrm{~mm}$ ile sirasiyla TTBM2017-2, Ada353, TTBM2017-3, TTBM2017-1, P31w86, TTBM2017-6, Komp. Beyaz, 
Tk353, TTBM2017-4 genotipleri ilk sırada yer alımıştır. Lokasyon genotip interaksiyonu bakımından incelendiğinde ise en geniş koçan çap $54.76 \mathrm{~mm}$ ile Bafra lokasyonu Kompozit Beyaz genotipte iken en düşük ise $38.89 \mathrm{~mm}$ ile Bafra lokasyonu Tk384 genotipte tespit edilmiştir (Çizelge 4). Ayrancı ve Sade (2004) 37.6 - $48.5 \mathrm{~mm}$ olduğu tespit edildikleri çalışmalar ile paralellik göstermektedir.

Koçan tane sayısı karakteri genotipler bakımından birleştirilmiş analiz sonucu; Ada353 genotipi 606.60 adet ile en yüksek iken, Tk534, Tk384 ve Tk353, genotipleri sirasiyla $321.55,399.25$ ve 403.60 adet ile en düşük olmuştur. Yapılan DUNCAN çoklu karşılaştırma testi sonucuna göre 606.60, 570.40, 550.60, 541.45 adet ile sirasiyla Ada353, P31w86, TTBM2017-1, TTBM2017-2, genotipleri ilk sirada yer alırmıştır. Lokasyon genotip interaksiyonu bakımından incelendiğinde ise en yüksek koçanda tane sayısı 634.80 adet ile Bafra lokastonu TTBM2017-1 genotipte iken en düşük ise 215.00 adet ile Bafra lokasyonu Tk534 genotipte tespit edilmiştir (Çizelge 5).

Genotipler ve genotip $\mathrm{x}$ lokasyon interaksiyonu bakımından birleştirilmiş analiz sonucunda Komp. Beyaz genotipi $350.41 \mathrm{~g}$ ile en yüksek iken, Tk534 ve Tk384 genotipleri sirasiyla 250.29 ve $218.00 \mathrm{~g}$ ile en düşük olmuştur. Yapılan DUNCAN çoklu karşılaştırma testi sonucuna göre 350.41, 346.62, 328.56, $319.09 \mathrm{~g}$ ile sirasiyla Komp. Beyaz, TBM2017-3, TTBM2017-2, P31w86 genotipleri ilk grupta yer almaktadır . Lokasyon genotip interaksiyonu bakımından incelendiğinde ise en yüksek bin tane ağırlığı $378.85 \mathrm{~g}$ ile Bafra lokasyonu Kompozit Beyaz genotipte iken en düşük ise $193.15 \mathrm{~g}$ ile Çarşamba lokasyonu Tk384 genotipte tespit edilmiştir (Çizelge 5). Ayrancı ve Sade (2004) 203 - 341 g; Palta ve ark. (2011) 217.5 g; Kuşvuran ve Nazlı (2014) 325 g olduğu tespit edildikleri çalışmalar ile paralellik göstermektedir.

Çizelge 5. Genotiplerin Bafra ve Çarşamba lokasyonu koçan tane sayısı ve bin tane ağırlığı ortalamaları

\begin{tabular}{|c|c|c|c|c|c|c|c|}
\hline \multirow{3}{*}{$\begin{array}{l}\text { Genotipler } \\
\text { TTBM2017-1 }\end{array}$} & \multicolumn{3}{|c|}{ Koçan tane sayısı (adet) } & \multicolumn{4}{|c|}{ Bin tane ağırlığı (g) } \\
\hline & Bafra & Çarşamba & Ortalama & Bafra & Çarşamba & \multicolumn{2}{|c|}{ Ortalama } \\
\hline & $634.80 \mathrm{a}$ & 466.40 efg & $550.60 \quad a b c$ & 314.47 b-f & 290.33 d-h & 302.40 & $\mathrm{bc}$ \\
\hline ТТВМ2017-2 & 470.70 efg & $612.20 \mathrm{abc}$ & 541.45 & $363.40 \mathrm{ab}$ & 293.72 d-g & 328.56 & $a b c$ \\
\hline ТТВМ2017-3 & $408.70 \mathrm{~g}$ & $491.50 \mathrm{c}-\mathrm{g}$ & 450.10 & $366.95 \mathrm{ab}$ & 326.28 a-e & 346.62 & $\mathrm{ab}$ \\
\hline ТTВМ2017-4 & $546.00 \mathrm{a}-\mathrm{f}$ & 463.90 efg & 504.95 & 285.26 d-h & $319.02 b-f$ & 302.14 & $\mathrm{bc}$ \\
\hline TTBM2017-5 & $509.70 \mathrm{~b}-\mathrm{g}$ & $407.60 \mathrm{~g}$ & 458.65 & $303.92 \mathrm{c}-\mathrm{f}$ & 269.09 e-h & 286.51 & $\mathrm{~cd}$ \\
\hline ТТВМ2017-6 & $394.40 \mathrm{~g}$ & $511.50 \mathrm{~b}-\mathrm{g}$ & 452.95 & $312.01 \mathrm{~b}-\mathrm{f}$ & $277.21 \mathrm{e}-\mathrm{h}$ & 294.61 & $\mathrm{~cd}$ \\
\hline Komp. Beyaz & 595.60 a-d & $407.80 \mathrm{~g}^{\circ}$ & 501.70 & 378.85 a & 321.96 a-f & 350.41 & $\mathrm{a}$ \\
\hline Ada353 & 586.20 a-e & $627.00 \mathrm{ab}$ & 606.60 & 337.86 a-d & 246.06 gh1 & 291.96 & $\mathrm{~cd}$ \\
\hline P31w86 & 564.20 a-e & 576.60 a-e & 570.40 & 286.22 d-h & $351.95 \mathrm{abc}$ & 319.09 & abc \\
\hline P2948w & $426.60 \mathrm{fg}$ & 478.60 d-g & 452.60 & 293.09 d-g & 288.31 d-h & 290.70 & $\mathrm{~cd}$ \\
\hline Tk353 & $417.20 \mathrm{~g}$ & $390.00 \mathrm{~g}$ & 403.60 & 274.19 e-h & 311.08 b-f & 292.63 & $\mathrm{~cd}$ \\
\hline Tk534 & $215.00 \mathrm{~h}$ & $428.10 \mathrm{fg}$ & 321.55 & $235.49 \mathrm{~h} 1$ & $265.08 \mathrm{fgh}$ & 250.29 & de \\
\hline Tk384 & 566.80 a-e & $231.70 \mathrm{~h}$ & 399.25 & 242.86 gh1 & 193.151 & 218.00 & $\mathrm{e}$ \\
\hline Ortalama & 487.38 & 468.68 & 478.03 & 307.28 & 288.71 & 297.99 & \\
\hline
\end{tabular}

* Aynı harfle gösterilen ortalamalar arasında fark yoktur.

Çizelge 6. Genotiplerin Bafra ve Çarşamba lokasyonu tane koçan oranı ve hasatta nem oranı ortalamaları

\begin{tabular}{|c|c|c|c|c|c|c|c|}
\hline \multirow[b]{2}{*}{ Genotipler } & \multicolumn{3}{|c|}{ Tane koçan oranı (\%) } & \multicolumn{4}{|c|}{ Hasat tane nemi (\%) } \\
\hline & Bafra & Çarşamba & Ortalama & Bafra & Çarşamba & Ort & ma \\
\hline TТВМ2017-1 & 83.47 & 83.20 & 83.33 & 23.73 b-f & $18.131 \mathrm{jk}$ & 20.93 & $\mathrm{bc}$ \\
\hline ТTВМ2017-2 & 82.57 & 83.93 & 83.25 & $22.27 \mathrm{fgh}$ & $18.201 \mathrm{jk}$ & 20.23 & $\mathrm{~cd}$ \\
\hline TTBM2017-3 & 80.27 & 83.73 & 82.00 & $25.30 \mathrm{~b}$ & $16.97 \mathrm{kl}$ & 21.13 & $\mathrm{bc}$ \\
\hline ТТВМ2017-4 & 83.03 & 82.13 & 82.58 & 22.80 e-h & $18.171 \mathrm{jk}$ & 20.48 & bcd \\
\hline TTBM2017-5 & 83.00 & 82.37 & 82.68 & $22.03 \mathrm{gh}$ & 19.331 & 20.68 & $\mathrm{bc}$ \\
\hline ТТВМ2017-6 & 83.47 & 81.67 & 82.57 & $23.03 \mathrm{~d}-\mathrm{g}$ & 19.371 & 21.20 & $\mathrm{bc}$ \\
\hline Komp. Beyaz & 82.20 & 82.33 & 82.27 & 19.471 & 16.431 & 17.95 & $\mathrm{e}$ \\
\hline Ada353 & 82.27 & 83.93 & 83.10 & $28.50 \mathrm{a}$ & $23.57 \mathrm{c}-\mathrm{g}$ & 26.03 & $\mathrm{a}$ \\
\hline P31w86 & 83.27 & 81.70 & 82.48 & $24.50 \mathrm{bcd}$ & $18.271 \mathrm{jk}$ & 21.38 & $\mathrm{bc}$ \\
\hline P2948w & 84.03 & 81.70 & 82.87 & 24.33 b-e & $18.201 \mathrm{jk}$ & 21.27 & $\mathrm{bc}$ \\
\hline Tk353 & 82.73 & 83.40 & 83.07 & $24.93 \mathrm{bc}$ & $18.57 \mathrm{ij}$ & 21.75 & $\mathrm{~b}$ \\
\hline Tk534 & 81.37 & 83.13 & 82.25 & $21.40 \mathrm{~h}$ & $17.40 \mathrm{jkl}$ & 19.40 & $\mathrm{~d}$ \\
\hline Tk384 & 81.37 & 82.10 & 81.73 & $22.20 \mathrm{fgh}$ & $18.50 \quad 1 \mathrm{jk}$ & 20.35 & $\mathrm{~cd}$ \\
\hline Ortalama & 82.54 & 82.72 & 82.63 & 23.42 & 18.55 & 20.98 & \\
\hline
\end{tabular}

* Aynı harfle gösterilen ortalamalar arasında fark yoktur.

Genotipler bakımından birleştirilmiş analiz sonucunda TTBM2017-1 çeşidi \% 83.33 ile en yüksek, Tk384 genotipi ise \% 81.73 ile en düşük bulunmuştur
(Çizelge 6). Öz ve Kapar (2003) \% 85.4; Öz ve ark. (2008) \% 80 - 88; Özata ve ark. (2013) \% 81.5 - 85.7; 
Öz ve Cengil (2016) \% 81.8 - 86.8 olduğu tespit edildikleri çalışmalar ile paralellik göstermektedir.

Genotipler bakımından birleştirilmiş analiz sonucunda hasat nemi bakımından, Ada353 genotipi \% 26.03 ile en yüksek iken, TTBM2017-4, Tk384, TTBM2017-2, ve Tk534 genotipleri sirasiyla \% 20.48, $20.35,20.23$ ve 19.40 ile en düşük olmuştur. Lokasyon genotip interaksiyonu bakımından incelendiğinde ise en yüksek hasat nemi \% 28.50 ile Bafra lokasyonu Ada353 genotipte iken en düşük ise \% 16.43 ve 17.40 ile sırasıyla Çarşamba lokasyonu Kompozit Beyaz ve Tk534 genotiplerinde tespit edilmiştir (Çizelge 6). Öz ve Kapar (2014) \% 29.0; Vartanlı ve Emeklier (2007) \% 21.15 - 28.60; Öz ve ark. (2008) \% 16.3 - 24.8; Tezel ve Aksoyak (2008) \% 15.1 - 23.3; Özata ve ark. (2013) \% 20.6 - 29.7; Öz ve Cengil (2016) \% 21.1 - 26. 6 olduğu tespit edildikleri çalışmalar ile paralellik göstermektedir.

Genotipler, lokasyon ve genotip $\mathrm{x}$ lokasyon interaksiyonu bakımından birleştirilmiş analiz sonucunda tane ham protein oran 1 Tk384, TTBM2017-4 ve Komp. beyaz genotipleri sirasiyla \% $12.85,12.38$ ve 12.42 ile en yüksek iken, Ada353, Tk534, TTBM2017-
1, Tk353, TTBM2017-5, P2948w, P31w86 ve TTBM2017-2 genotipleri sirasiyla \% 10.62, 10.67, $10.68,11.05,11.08,11.14,11.15,11.19$ ile en düşük olmuştur. Lokasyon genotip interaksiyonu bakımından incelendiğinde ise en yüksek ilk koçan yüksekliği \% 13.60 ile Çarşamba lokasyonu Tk384 genotipte iken en düşük ise \% 9.31 ile Çarşamba lokasyonu TTBM2017-1 genotipte tespit edilmiştir (Çizelge 7). Vartanlı ve Emeklier (2007) \% 6.21 - 8.65; Olson ve Frey (1987) \% 9.9 olduğu tespit edildikleri çalışmalar ile paralellik göstermektedir.

Genotipler bakımından birleștirilmiş analiz sonucunda TTBM2017-3, TTBM2017-5, Tk 534 ve Tk384 genotipleri sirasiyla \% 5.45, 4.80, 4.69 ve 4.49 ile en yüksek olmuştur. Lokasyon genotip interaksiyonu bakımından incelendiğinde ise en yüksek yağ oranı \% 6.02 ile Bafra lokasyonu TTBM2017-3 genotipte iken en düşük ise \% 2.30 ile Bafra lokasyonu Kompozit Beyaz genotipte tespit edilmiştir (Çizelge 7). Olson ve Frey (1987) \% 3.5 - 6.0; Vartanlı ve Emeklier (2007) \% $2.04-6.90$ olduğu tespit edildikleri çalışmalar ile paralellik göstermektedir.

Çizelge 7. Genotiplerin Bafra ve Çarşamba lokasyonu tane ham protein oranı ve tane ham yağ oranı ortalamaları

\begin{tabular}{|c|c|c|c|c|c|c|c|c|}
\hline & \multicolumn{4}{|c|}{ Tane ham protein oranı (\%) } & \multicolumn{4}{|c|}{ Tane ham yağ oranı (\%) } \\
\hline Genotipler & Bafra & Çarșamba & Orta & ma & Bafra & Çarșamba & & ama \\
\hline TTBM2017-1 & $12.05 \mathrm{~cd}$ & $9.31 \quad 1$ & 10.68 & $\mathrm{c}$ & $3.88 \mathrm{~d}-1$ & $4.02 \mathrm{~d}-1$ & 3.95 & $\mathrm{~b}$ \\
\hline TTBM2017-2 & $12.27 \mathrm{bcd}$ & 10.12 h1 & 11.19 & $\mathrm{c}$ & $3.44 \mathrm{~g}-\mathrm{j}$ & $4.52 \mathrm{~b}-\mathrm{h}$ & 3.98 & $\mathrm{~b}$ \\
\hline TTBM2017-3 & 11.91 cde & $11.18 \mathrm{~d}-\mathrm{h}$ & 11.54 & bc & $6.02 \mathrm{a}$ & $4.89 \mathrm{a}-\mathrm{f}$ & 5.45 & $\mathrm{a}$ \\
\hline TTBM2017-4 & $13.46 \mathrm{ab}$ & $11.31 \mathrm{~d}-\mathrm{h}$ & 12.38 & $\mathrm{ab}$ & $3.20 \mathrm{~h}-\mathrm{j}$ & 5.16 a-e & 4.18 & $\mathrm{~b}$ \\
\hline TTBM2017-5 & $11.49 \mathrm{~d}-\mathrm{g}$ & $10.66 \mathrm{e}-\mathrm{h}$ & 11.08 & $\mathrm{c}$ & $4.10 \mathrm{~d}-1$ & $5.51 \mathrm{abc}$ & 4.80 & $a b$ \\
\hline ТTВМ2017-6 & $11.90 \mathrm{cde}$ & $11.15 \mathrm{~d}-\mathrm{h}$ & 11.52 & $\mathrm{bc}$ & $3.24 \mathrm{~h}-\mathrm{j}$ & $4.50 \mathrm{c}-\mathrm{h}$ & 3.87 & $\mathrm{~b}$ \\
\hline Komp. Beyaz & $13.03 \mathrm{abc}$ & $11.82 \mathrm{c}-\mathrm{f}$ & 12.42 & $\mathrm{ab}$ & $2.30 \mathrm{j}$ & $5.86 \mathrm{ab}$ & 4.08 & $\mathrm{~b}$ \\
\hline Ada353 & $11.12 \mathrm{~d}-\mathrm{h}$ & $10.12 \mathrm{~h} 1$ & 10.62 & $\mathrm{c}$ & $3.49 \mathrm{~g}-\mathrm{j}$ & $4.12 \mathrm{~d}-1$ & 3.80 & $\mathrm{~b}$ \\
\hline P31w86 & $11.60 \mathrm{def}$ & 10.70 e-h & 11.15 & $\mathrm{c}$ & $4.44 \mathrm{c}-1$ & $3.49 \mathrm{~g}-\mathrm{j}$ & 3.96 & $\mathrm{~b}$ \\
\hline P2948w & $11.73 \mathrm{c}-\mathrm{f}$ & $10.54 \mathrm{f}-1$ & 11.14 & $\mathrm{c}$ & $3.09 \mathrm{1j}$ & $4.65 \mathrm{~b}-\mathrm{g}$ & 3.87 & $\mathrm{~b}$ \\
\hline Tk353 & $11.95 \mathrm{cde}$ & $10.14 \mathrm{hi}$ & 11.05 & $\mathrm{c}$ & $3.74 \mathrm{f}-1$ & $4.05 \mathrm{~d}-1$ & 3.89 & $\mathrm{~b}$ \\
\hline Tk534 & $10.23 \mathrm{gh} 1$ & $11.11 \mathrm{~d}-\mathrm{h}$ & 10.67 & $\mathrm{c}$ & 4.88 a-f & $4.50 \mathrm{c}-\mathrm{h}$ & 4.69 & $a b$ \\
\hline Tk384 & $12.10 \mathrm{~cd}$ & $13.60 \mathrm{a}$ & 12.85 & $\mathrm{a}$ & $3.80 \mathrm{e}-1$ & 5.18 a-d & 4.49 & $a b$ \\
\hline Ortalama & 11.91 & 10.90 & 11.41 & & 3.81 & 4.65 & 4.23 & \\
\hline
\end{tabular}

* Aynı harfle gösterilen ortalamalar arasında fark yoktur.

Çizelge 8. Genotiplerin tane verimi değerleri $(\mathrm{kg} / \mathrm{da})$

\begin{tabular}{|c|c|c|c|c|c|c|c|c|c|c|c|c|}
\hline Genotipler & \multicolumn{4}{|c|}{ Bafra } & \multicolumn{4}{|c|}{ Çarşamba } & \multicolumn{4}{|c|}{ Ortalama } \\
\hline TTBM2017-1 & 1159.45 & \pm & 41.06 & $a b c$ & 858.82 & \pm & 65.26 & c-g & 1009.14 & \pm & 54.20 & $a b$ \\
\hline ТTВМ2017-2 & 1026.25 & \pm & 64.51 & $b-f$ & 1150.75 & \pm & 7.64 & $a-d$ & 1088.50 & \pm & 57.27 & $\mathrm{a}$ \\
\hline ТTВМ2017-3 & 842.63 & \pm & 95.76 & d-g & 1031.85 & \pm & 58.12 & $b-f$ & 937.24 & \pm & 71.81 & $a b c$ \\
\hline TТВМ2017-4 & 931.89 & \pm & 100.40 & $c-g$ & 941.61 & \pm & 79.76 & $c-g$ & 936.74 & \pm & 116.26 & $a b c$ \\
\hline TTBM2017-5 & 930.16 & \pm & 46.53 & $c-g$ & 687.63 & \pm & 21.49 & g & 808.97 & \pm & 75.36 & $\mathrm{bc}$ \\
\hline ТTВМ2017-6 & 734.85 & \pm & 69.57 & fg & 879.72 & \pm & 65.89 & c-g & 807.28 & \pm & 293.01 & $\mathrm{bc}$ \\
\hline Komp. beyaz & 1390.91 & \pm & 60.08 & $\mathrm{a}$ & 850.40 & \pm & 20.69 & $c-g$ & 1120.65 & \pm & 55.19 & $\mathrm{a}$ \\
\hline Ada353 & 1103.60 & \pm & 39.12 & a-e & 927.97 & \pm & 61.79 & $c-g$ & 1014.29 & \pm & 75.42 & $a b$ \\
\hline P31w86 & 951.41 & \pm & 96.65 & $c-g$ & 1284.94 & \pm & 90.83 & $a b$ & 1118.17 & \pm & 84.93 & $\mathrm{a}$ \\
\hline P2948w & 750.21 & \pm & 13.55 & $f g$ & 861.41 & \pm & 100.76 & $c-g$ & 805.81 & \pm & 78.04 & $\mathrm{bc}$ \\
\hline Tk353 & 680.75 & \pm & 30.12 & $\mathrm{~g}$ & 781.68 & \pm & 34.71 & fg & 731.21 & \pm & 34.80 & $\mathrm{~cd}$ \\
\hline Tk534 & 304.59 & \pm & 23.56 & $\mathrm{~h}$ & 771.91 & \pm & 16.12 & fg & 538.25 & \pm & 22.25 & $\mathrm{~d}$ \\
\hline Tk384 & 816.22 & \pm & 21.37 & efg & 279.46 & \pm & 78.18 & $\mathrm{~h}$ & 547.84 & \pm & 83.81 & d \\
\hline Ortalama & 894.08 & \pm & 179.21 & & 869.63 & \pm & 207.45 & & 881.85 & \pm & 192.60 & \\
\hline
\end{tabular}

* Aynı harfle gösterilen ortalamalar arasında fark yoktur. 
Genotipler bakımından birleștirilmiş analiz sonucunda Komp. beyaz genotipi $1120.65 \mathrm{~kg} / \mathrm{da}$ ile en yüksek tane verimi iken, Tk534 genotipi $538.25 \mathrm{~kg} / \mathrm{da}$ ile en düşük olmuştur. Yapılan DUNCAN çoklu karşılaştırma testi sonucuna göre TTBM2017-1, TTBM2017-2, TTBM2017-3, TTBM2017-4, Komp. Beyaz, Ada353 ve P31w86 genotipleri sirasiyla 1009.14, 1088.50, 937.24 936.74, 1120.65 ve 1118.17 $\mathrm{kg} / \mathrm{da}$ ile ilk sirada yer alırken, son grupta ise 731.21 , 538.25 ve $547.84 \mathrm{~kg} / \mathrm{da}$ ile sirasiyla Tk353, Tk534 ve Tk384 genotipleri yer almıştır. Lokasyon bakımından incelendiğinde, Bafra lokasyonu ile Çarşamba lokasyonu arasında $24.45 \mathrm{~kg} / \mathrm{da}$ fark olduğu tespit edilmiştir. Lokasyon genotip interaksiyonu bakımından incelendiğinde ise en yüksek tane verimi $1390.91 \mathrm{~kg} / \mathrm{da}$ ile Bafra lokasyonu Ada353 genotipte iken en düşük ise $279.46 \mathrm{~kg} / \mathrm{da}$ ile Çarşamba lokasyonu Tk384 genotipte tespit edilmiştir (Çizelge 8). Ayrancı ve Sade (2004) $644-1091 \mathrm{~kg} / \mathrm{da}$; Öz ve Kapar (2003) 845 - 1190 kg/da; Tiftikçi ve Egesel (2011) $1039.7-1272.5 \mathrm{~kg} / \mathrm{da}$; Öz ve ark. (2008) 949.0 - $1258.0 \mathrm{~kg} / \mathrm{da}$; Tezel ve Aksoyak (2008) 616.0 - 1375.0 kg/da; Özata ve ark. (2013) 909.4 - $1224.0 \mathrm{~kg} / \mathrm{da}$; Y1lmaz ve Han (2016) 1607.0 kg/da; Özata ve Öz (2014) 738.0 - 1098.6 kg/da; Öz ve Cengil (2016) 899.0 - 1193.0 olduğu tespit edildikleri çalışmalar ile paralellik göstermektedir.

\section{Sonuç}

İnsanoğlunun kültüre aldığ1 en eski tarla bitkilerinden biri olan mısır, yüksek verim yanında, hayvan yemi, endüstride ve özellikle insan yiyeceği olarakta beyaz atdişi ile sert misır çeşitlerinin Karadeniz bölgesi için özel bir önemi vardır. Ülkemizde hibrit mısır tohumluğunun yaklaşı \% 95'ini yabancı çeşitler oluşturmakta, yerli çeşitlerimizin pay1 \% 5 'i geçmemektedir.

$\mathrm{Bu}$ çalışmada, en yüksek tane verimi $1390.91 \mathrm{~kg} / \mathrm{da}$ ile Bafra lokasyonunda Ada353 genotipte elde edilirken, en düşük ise $279.46 \mathrm{~kg} / \mathrm{da}$ ile Carşamba lokasyonunda Tk384 genotipinde tespit edilmiştir. Bafra ve Çarşamba lokasyonları birlikte değerlendirildiğinde Ada353, P31w86, TTBM2017-2 genotipleri sirasiyla 1120.65, 1118.17 ve $1088.50 \mathrm{~kg} / \mathrm{da}$ ile en yüksek tane verimine sahip iken, Tk534 genotipi $514.17 \mathrm{~kg}$ ile en düşük tane verimine sahip olmuştur. Tane verimi bakımından incelendiğinde, Bafra lokasyonu için Ada353 genotipi ön plana çıkarken, Çarşamba lokasyonunda ise P31w86 genotipi diğer genotipleri geride bırakmıştır. Bu iki çeşit diğer genotiplerden daha üstün olduğu için bölge için önerilmektedir. Ayrıca, tanede ham yağ oranı bakımından TTBM2017-3 genotipi, tanede ham protein oranı bakımdan ise Tk384 genotipi önerilebilir.

\section{Teșekkür}

Bu çalışma Ondokuz Mayıs Üniversitesi tarafından desteklenen PYO.ZRT.1904.17.050 nolu projeden üretilmiştir.

\section{Kaynaklar}

Anonim, 2001. Tarımsal değerleri ölçme denemeleri teknik talimatı (Misır-Zea mays L.). www.tugem.gov.tr/document/misir_teknik_talimati. doc. Ankara.

Anonim, 2010. Tarımsal değerleri ölçme denemeleri teknik talimatı (Misır-Zea mays L.). www.tugem.gov.tr/ document/misir_teknik_talimati.doc. Ankara

Anonim, 2019. Misır durum/tahmin raporu.tarımsal ekonomi ve politika geliştirme enstitüsü, https://arastirma.tarimorman.gov.tr/tepge/Belge ler/PDF\%20Durum-

Tahmin\%20Raporlar\%C4\%B1/ 2018 2019\%20Durum-\%20Tahmin\%20Raporlar/M\% C4\%B1s\%4\%B1r\%20Durum\%20Tahmin\%20

Raporu\%202017-2018-308.pdf . (Erişim tarihi: 25.05.2019)

Ayrancı, R., B. Sade., 2004. Konya ekolojik şartlarında yetiştirilebilecek atdişi melez misır (Zea mays L. indentata Sturt.) çeşitlerinin belirlenmesi. Bitkisel Araştırma Dergisi, (2004) 2: 6-14, Konya

Bayramoğlu, Z., Bozdemir, M., 2018. Türkiye' de üretilen mısırın ekonomik gelişim seyri. Türk Tarım Gida Bilim ve Teknoloji Dergisi, 6(8): 1092-1100.

Cengiz, R., 2006. Misır hatları arasındaki 8x8 yarım diallel melez döllerinde verim ve verim unsurlarının kalıtımları üzerine araştırmalar, Yüksek Lisans Tezi, Trakya Üniversitesi Fen Bilimleri Enstitüsü, Tekirdağ, $160 \mathrm{~s}$.

Cengiz, R., 2016. Türkiye'de kamu mısır araştırmaları, Tarla Bitkileri Merkez Araştırma Enstitusu Dergisi, 2016, 25 (Özel say1-1):304-310

Dudley, J.W., Moll R.H., 1969. Interpretation and use of estimates of heritability and genetic variances in plant breeding. Crop Sci. 9: 257-261.)

Gençtürk, F., 2007. Bazı silajlık mısır çeşitlerinin Erzurum ovası koşullarında yetiştirilme olanakları üzerine bir araştırma. Atatürk Üniversitesi, Fen Bilimleri Enstitüsü, Yüksek Lisans Tezi.

Kırtok, Y., 1998. Mısır üretimi-3, Cine Tarım Dergisi, Aylık Tarım Dergisi, Y11:1, Sayı:11, s:24-25.

Kuşvuran, A., Nazlı, R., 2014. Determination of grain maize properties of some maize (Zea mays L.) cultivars under middle Kizilirmak basin ecological conditions. Yüzüncü Yıl Üniversitesi Tarım Bilimleri Dergisi , 24 (3) , 233-240 。 DOI: $10.29133 /$ yyutbd.236254 
Kün, E., 1997, Tahıllar II (Sıcak İklim Tahılları), Ank. Üniv. Ziraat Fak. Yay. No: 1452, Ders Ktiab1 No: 432, Ankara.

Olson, R.A., Frey, K..J., 1987. Nutritional quality of cereals grains: genetic and agronomic improvement, American Society of Agronomy. Number 28, 511 pps, USA,

Öner, F., Aydın, İ., Sezer, İ., Gülümser, A., Mut, Z., 2011. Samsun koşullarında bazı hibrit misır çeşitlerinin verim ve kalite özelliklerinin belirlenmesi. Türkiye 9. Tarla Bitkileri Kongresi s:559-562, Bursa.

Öner, F., Gulumser, A., 2014. Determination of some agronomical characteristics of local flint corn (Zea mays $L$. indurata) genotypes in the black sea region of turkey. Turkish Journal of Agricultural and Natural Sciences, Special Issue: 2, 2014.

Öz, A., Cengil, B., 2016. A Study on adaptation of some maize cultivar in middle Kizılırmak basin. Journal of Applied Biological Sciences, 10(1): 1-7.

Öz, A., Kapar, H., 2003. Samsun koşullarında geliştirilen çeşit adayı mısırların verim öğelerinin belirlenmesi ve stabilite analizi. Ankara Üniv., Zir. Fak., Tarım Bilimleri Der., Cilt:9 (4), 454-459.

Öz, A., Tezel, M., Kapar, H., Üstün, A., 2008. Samsun ve Konya şartlarına uygun mısır çeşitlerinin geliştirilmesi üzerine bir araştırma. Ülkesel Tahıl Sempozyumu, 2-5 Haziran 2008, Konya, 137-146.

Özata, E., Geçit, H.H., Öz, A., Ünver İkincikarakaya, S., 2013. Atdişi hibrit mısır adaylarının ana ürün koşulla- rında performanslarının belirlenmesi. Iğdır Üniversitesi Fen Bilimleri Enstitüsü Dergisi Yıl: 2013 - Cilt: 3 - Say1: .

Özata, E., Kapar, H. 2011. Atdişi mısır yoklama melezlerinin verim ve bazı verim öğeleri. Türkiye 9 . Tarla Bitkileri Kongresi s:441-444, Bursa.
Özata, E., Öz. A., 2014. Atdişi hibrit mısır adaylarının ana ürün koşullarında verim ve kalite özelliklerinin belirlenmesi. Tarım Bilimleri Araştırma Dergisi 7 (2): 01-07, 2014.

Palta, C., Karadavut, U., Tezel, M., \& Aksoyak, S. (2011). Agronomic performance of some corn cultivars (Zea mays L.) in Middle Anatolia. Journal of Animal and Veterinary Advances, 10(14), 19011905.

Sayaslan A., Gökmen S., Ülger A.C., Sakin M.A., Öz A. ve Duman A., 2010. Farklı bölgelerde ana ürün koşullarında yetiştirilen melez atdişi mısır (Zea mays indentata L.) Çeşitlerinin verim ve yaş ögütme kalitesinin belirlenmesi. TOVAG-1070800 Nolu Proje Sonuç Raporu, s. 76

Sezer İ. ve Gülümser A., 1999. Çarşamba ovasında ana ürün olarak yetiştirilebilecek misır çeşitlerinin belirlenmesi üzerine bir araştırma. Türkiye 3. Tarla Bitkileri Kongresi. C.1. Genel Tahıllar, 275-280. 1518 Kasim 1999 Adana.

Tezel M, Aksoyak Ş (2008). Konya koşullarında bazı tek melez misir genotiplerinin performanslarının belirlenmesi. Bitkisel Araştırma Dergisi. 2: 1-4

Tiftikci, H., Egesel, C.Ö., 2011. Türkiye'de yetiştirilen melez mısır çeşitlerinin bazı tarımsal özellikler bakımından incelenmesi, Çanakkale Onsekiz Mart Üniversitesi, Fen Bilimleri Enstitüsü, Yüksek Lisans Tezi. Çanakkale.

Vartanlı S, Emeklier HY (2007). Ankara koşullarında hibrit mısır çeşitlerinin verim ve kalite özelliklerinin belirlenmesi. Tarım Bilimleri Dergisi. 13 (3): 195202.

Y1lmaz, N., Han, E., 2016. Giresun ekolojik koşullarında bazı mısır çeşitlerinin tane verimi ve verim ögelerinin belirlenmesi, Iğdır Üni. Fen Bilimleri Enst. Der. 6(3): 171-176, 2016 